There is no substitute for general, unrestricted institutional support. Slavens hints that Union librarians have subsequently experienced difficulty handling numerous special collections encumbered with names and conditions (p.337), but the collections would clearly not be the fine resources they are today without the support of both the donors and the parent institution. The critical role of the faculty in building a fine collection for teaching and research is also emphasized throughout this work. They actively recommended particular acquisitions (although this is too often asserted without documentation), promoted theological bibliography, and donated their own working collections. Their partnership with Union's librarians is worthy of emulation.-Jonathan LeBreton, Albin O. Kuhn Library \& Gallery, University of Maryland, Baltimore County, Catonsville.

\title{
OTHER PUBLICATIONS
}

Acronyms, Initialisms, and Abbreviations Dictionary: A Guide to More Than 400,000 Alphabetic Designations, Contractions, Acronyms, Initialisms, Abbreviations, and Similar Condensed Appellations. 11th ed. Ed. by Julie E. Towell and Helen E. Sheppard. Detroit: Gale, 1986. 2,928p. set, \$180(ISBN 0-8103-4317-7). LC 84643188 .

Agricultural Research Centres: A World Directory of Organizations and Programmes. London: Longman (dist. by Gale), 1986. 2v. 1,138p. set, \$395 (ISBN 0-582-90033-6).

American Literary Publishing Houses, 1638-1899. Ed. by Peter Dzwonkoski. Detroit: Gale, 1986. 2v. 715p. \$176 (ISBN 0-8103-1727-3). LC 86-2210.

American Men and Women of Science: Physical and Biological Sciences. 16th ed. Ed. by Jaques Cattell Pr. New York: Bowker, 1986. 8v. 7,685p. set, \$595 (ISBN 0-8352-2221-7). LC 6-7326.

American Poets, 1880-1945: Third Series. Ed. by Peter Quartermain. Dictionary of Literary Biography, v.54. Detroit: Gale, 1986. 2v. 743p. \$180 (ISBN 0-8103-1732-X). LC 86-19562.

Ballou, Patricia K. Women: A Bibliography of Bibliographies. 2d ed. Boston: G. K. Hall, 1986. 268p. \$30 (ISBN 0-8161-8729-0). LC 86-18475.

Baseball: A Comprehensive Bibliography. Comp. by Myron J. Smith, Jr. Jefferson, N.C.: McFarland, 1986. 864p. \$55 (ISBN 0-89950-2229). LC $85-43592$.

Best Places to Stay in America's Cities: Unique Hotels, City Inns, and Bed \& Breakfasts. Ed. by Kenneth Hale. Boston: Harvard Common Pr., 1986. 400p. paper, \$9.95 (ISBN 0-91678281-6). LC 86-19369.

Book Review Index: Periodical Reviews 1976-1984. Ed. by Barbara Beach. Detroit: Gale, 1986. 295p. \$75 (ISBN 0-8103-4364-9). LC 86-22846.

Canadian Writers since 1960: First Series. Ed. by W. H. New. Dictionary of Literary Biography, v.53. Detroit: Gale, 1986. 445p. \$88.

Cheng, Peter P. Chronology of The People's Re- public of China: 1970-1979. Metuchen, N.J.: Scarecrow, 1986. 629p. \$55 (ISBN 0-81081751-9). LC 84-20231.

Children's Authors and Illustrators: An Index to Biographical Dictionaries. 4th ed. Ed. by Joyce Nakamura. Gale Biographical Index Series, no. 2. Detroit: Gale, 1986.799p. $\$ 140$ (ISBN 08103-2525-X).

Children's Literature Review: Excerpts from Reviews, Criticism, and Commentary on Books for Children: V.11. Ed. by Gerard J. Senick. Detroit: Gale, 1986. 293p. \$78 (ISBN 0-81030343-4). LC 75-34953.

Cimbala, Diane J., Jennifer Cargill, and Brian Alley. Biographical Sources: A Guide to Dictionaries and Reference Works. Phoenix, Ariz.: Oryx, 1986. 146p. \$35 (ISBN 0-89774-136-6). LC 86-12805.

The Complete Directory of Japan 1986-87. Hong Kong: International Culture Institute (dist. by Gale), 1986. 1,074p. $\$ 200$.

Contemporary Theatre, Film, and Television. V.3. Ed. by Monica M. O'Donnell. Detroit: Gale, 1986. 450p. \$92 (ISBN 0-8103-2066-5). LC 84649371.

Contemporary Authors. V.118. Ed. by Hal May. Detroit: Gale, 1986. 844p. \$88 (ISBN 0-81031918-7). LC 62-52046.

Directory of European Industrial and Trade Associations. 4th ed. Ed. by Richard Leigh. Detroit: Gale, 1986. 406p. \$195 (ISBN 0-900246-46-4). LC 74-175919.

The Europa Year Book 1986: A World Survey. 27th ed. London: Europa (dist. by Gale), 1986. 2v. 3,089 p. set, \$235 (ISBN 0-946653-14-3). LC 592942.

Freris, A. F. The Greek Economy in the Twentieth Century. New York: St. Martin's, 1986. 226p. \$29.95 (ISBN 0-312-34724-3). LC 86-6669.

Gillespie, Michael Patrick. James Joyce's Trieste Library: A Catalogue of Materials at the Harry Ransom Humanities Research Center, the University of Texas at Austin. Austin: Univ. of 


\section{Make Full Use of Your Book Review Digest Collection} Book Review Digest
Author/Title

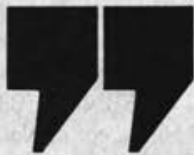

"A handy, useful, accurate index to a standard library tool."

-REFERENCE AND

SUBSCRIPTION BOOKS REVIEWS

(On the 1905-1974 Index)

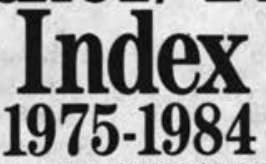

1,488pp. 1986 ISBN 0-8242-0729-7 $\$ 65$ U.S. and Canada, $\$ 75$ other countries.
New Flat Rates for Retrospective Volumes

Is your Book Review Digest collection complete?

Annual cumulative volumes of
A single-alphabet index offering author and title access to the nearly 60,000 books covered in Book Review Digest from 1975 through 1984 , this volume leads you to reliable reviews of many of the most significant works published in the past decade. Covering fiction and nonfiction English-language books published or distributed in the United States or Canada, Book Review Digest has earned its place as one of the reference librarian's most trusted resources. This new Index makes the annual volumes of $B R D$ even more valuable for your library.

\section{Easy Access to Ten Years of Coverage}

This index offers access to the reviewed books by title and names of authors, compilers, editors, joint authors, or translators. Each entry provides the year that reviews for the book were cited in $B R D$. Cross-references to the preferred forms of names of persons, institutions, and corporations speed research.

\section{Eighty Years of Reviews-}

\section{All Annual Volumes Kept in Print}

The new ten-year Index combines with the previously published Book Review Digest Author/Title Index 1905-1974 to direct researchers to the eighty annual volumes of $B R D$ published from 1905-1984, covering reviews of some 350,000 books. The Wilson Company keeps all of the $B R D$ volumes in print, to assure users of a permanent tool for reference, research, and evaluation of this century's literary output.
$B R D$ from 1970-1979 have just been made available at special flat rates. Now all $B R D$ volumes from 1905 to 1979 can be purchased at these special low rates, making this the perfect time to fill the gaps in your collection. Book Review Digest A Reputation for Excellence

Providing excerpts from and citations to reviews of current adult and juvenile fiction and non-fiction, Book Review Digest covers nearly 6,000 books each year. These concise, critical evaluations are culled from more than eighty selected American, British, and

Canadian periodicals in the humanities, social sciences, and general science areas,

in addition to library review media.

For Reference, Research, and

\section{Collection Development}

Book Review Digest offers subject access to book reviews in a separate Subject and Title Index. It also provides subject headings for adult fiction under "Fiction themes." Separate sections cover juvenile literature-divided into three grade groups - and biographies.

\section{Your Annual Subscription}

A subscription to Book Review Digest brings your library ten monthly paperbound issues plus a permanent annual clothbound cumulation. $B R D$ is sold on the service basis (book budget).

To Order, Call Toll-Free: 1-800-367-6770

In New York State, call 1-800-462-6060;

in Canada, call collect 212-588-8400. 
Texas, 1986. 276p. \$30 (ISBN 0-87959-105-6).

Guide to Research Collections of Former United States Senators, 1789-1982. Ed. by Kathryn Allamong Jacob. Detroit: Gale, 1986. 389p. $\$ 92$ (ISBN 0-8103-2224-2). LC 86-23953.

Handbook of Nations: A Brief Guide to the Economy, Government, Land, Demographics, Communications, and National Defense Establishments of Each of 206 Nations and Other Political Entities. 6th ed. Detroit: Gale, 1986. 292p. \$78 (ISBN 0-8103-1590-4).

Hanson, Patricia King, and Stephen L. Hanson. Film Review Index: Volume 1: 1882-1949. Phoenix: Oryx, 1986. 397p. $\$ 58.50$ (ISBN 089774-153-6). LC 85-43369.

Hargraves, Michael. Harry Crews: A Bibliography. Westport, Conn.: Meckler, 1986. 100p. \$19.50 (ISBN 0-88736-060-2). LC 86-12885.

Harmon, Robert B. The Collectible John Steinbeck: A Practical Guide. Jefferson, N.C.: McFarland, 1986. 200p. \$20 (ISBN 0-89950-206-7). LC 8543578.

Imperato, Pascal James. Historical Dictionary of Mali. 2d ed. African Historical Dictionaries, no.11. Metuchen, N.J.: Scarecrow, 1986. 359p. $\$ 32.50$ (ISBN 0-8108-1885-X). LC 861877.

International Authors and Writers Who's Who. 10 th ed. Ed. by Ernest Kay. Cambridge, England: Intntl. Biographical Centre (dist. by Gale), 1986. 879p. \$145 (ISBN 0-900332-88-3).

The Later Works of John Dewey 1925-1953: Vol. 9, 1933-1934. Ed. by Jo Ann Boydston. Carbondale: Southern Illinois Univ. Pr., 1986. 550p. $\$ 30$ (ISBN 0-8093-1265-4). LC 80-27285.

Managing the Multinational Subsidiary. Ed. by Hamid Etemad and Louise Seguin Dulude. New York: St. Martin's, 1986. 225p. \$32.50 (ISBN 0-312-51229-5). LC 86-13936.

Materials Research Centres: $A$ World Directory of Organizations and Programmes. $2 \mathrm{~d}$ ed. London: Longman (dist. by Gale), 1986. 814p. \$275 (ISBN 0-582-90031-X).

Medical Research Centres: A World Directory of Organizations and Programmes. 7th ed. London: Longman (dist. by Gale), 1986. 2v. 1,080p. set, $\$ 395$ (ISBN 0-582-90032-8).

Mohlenbrock, Robert H., and Paul M. Thomson, Jr. Flowering Plants: Smartweeds to Hazelnuts. Illustrated Flora of Illinois. Carbondale: Southern Illinois Univ. Pr., 1986. 228p. \$35 (ISBN 0-8093-1104-6). LC 86-6698.

Nineteenth-Century Literature Criticism: Excerpts from Criticism of the Works of Novelists, Poets, Playwrights, Short Story Writers, Philosophers, and Other Creative Writers Who Died between 1800 and 1900 . V.13. Ed. by Cherie D. Abbey. Detroit: Gale, 1986. 531p. \$88 (ISBN 0-81035813-1). LC 81-6943.

Publishers Directory 1987. Ed. by Linda S. Hubbard. Detroit: Gale, 1986. 2v. 2,187p. $\$ 250$ (ISBN 0-8103-0414-7). LC 84-645506.

Research Centers Directory: A Guide to Approximately 9,200 University-Related and Other NonProfit Research Organizations Established on a Permanent Basis and Carrying on Continuing Research Programs. 11th ed. Ed. by Mary Michelle Watkins. Detroit: Gale, 1986. 2v. 1,770p. $\$ 355$ (ISBN 0-8103-0472-4). LC 6014807.

Rhodes, P. J. The Greek City States: A Source Book. Norman: Univ. of Oklahoma Pr., 1986. 226p. $\$ 28.50$ (ISBN 0-8061-2010-X). LC 863375.

Talab, R. S. Commonsense Copyright: $A$ Guide to the New Technologies. Jefferson, N.C.: McFarland, 1986. 162p. paper, $\$ 14.95$ (ISBN 089950-224-5). LC 85-43593.

Twentieth-Century Literary Criticism. V.21. Ed. by Dennis Poupard. Detroit: Gale, 1986. 575p. \$88 (ISBN 0-8103-2403-2). LC 76-46132.

The United States Newspaper Program: Cataloging Aspects. Ed. by Ruth C. Carter. New York: Haworth, 1986. 119p. \$22.95 (ISBN 0-86656576-0). LC 86-4828.

The Video Source Book. 8th ed. Detroit: Gale, 1986. 2,224p. \$149 (ISBN 0-935478-32-9). LC 82-61690.

The World Almanac of the American West. Ed. by John S. Bowman. New York: Pharos, 1986. 368p. $\$ 29.95$ (ISBN 0-345-33720-4). LC 85052319. 